\title{
Hidrogel injektagarriak eta haien aplikazioak ehun ingeniaritzan
}

(Injectable hydrogel and its applications in tissue engineering)

\author{
Sheila Maiz-Fernández, ${ }^{1,2 *}$, Leyre Pérez-Álvarez ${ }^{1,2}$, Leire Ruiz-Rubio ${ }^{1,2}$, \\ José Luis Vilas-Vilela ${ }^{1,2}$
}

${ }^{1}$ Kimika Makromolekularreko taldea (LABQUIMAC), Euskal Herriko Unibertsitatea

(UPV/EHU)

${ }^{2}$ BCMaterials, Basque Centre for Materials, Applications and Nanostructures

LABURPENA: Ehun ingeniaritzak kaltetuta dauden ehunen ordezko funtzionalak sintetizatzeko helburua dauka. Horretarako, zelulaz, molekula bioaktiboz eta euskarri porotsuz osatutako matrizeak beharrezkoak dira, hazkuntza eta zelulen diferentziazio prozesuak gerta daitezen. Matrize horiek solidotzeko gai den aitzindari baten injekzioz eratu daitezke kaltetuta dauden ehunetan. Hori dela eta, hidrogel injektagarriak ikerkuntza arlo biomedikoan izugarri hedatu dira azken urteotan. Biomaterial horien injektagarriak izateko gaitasuna sare polimerikoen in situ gurutzaketan oinarritzen da. Gurutzaketa horiek, alde batetik, interakzio fisiko itzulgarrien bidez gerta daitezke. Hala, hidrogel termosentikorrak, pH-sentikorrak edo ionikoak eratzen dira. Bestalde, erreakzio kimikoetan ere oinarritu daitezke, zeinetan hidrogel fotopolimerizagarriak edo entzimek katalizatutako gurutzaketa bidezko hidrogelak lor daitezkeen. Lan honen helburua da hidrogel injektagarriak sintetizatzeko erabiltzen diren estrategien eta ehun ingeniaritzan ikertutako sistemen aplikazioen berrikuspen bat egitea.

HITZ GAKOAK: Polimero, hidrogel, injektagarri, gurutzaketa, biomaterial.

\begin{abstract}
Tissue engineering aims to create functional substitutes for damaged or diseased tissues through complex constructions of living cells, bioactive molecules and three-dimensional porous scaffolds that support the union, proliferation and differentiation of cells. These constructions can be formed by injection of a precursor which can solidify into the defective tissue, which has converted biomaterials such as injectable hydrogels into one of the most promising biomedical research areas of recent years. Injectable hydrogels are based on the in-situ crosslinking of polymer networks. The mechanisms involved in the formation of these gels can be very varied, and are based on both reversible physical interactions, forming thermosensitive hydrogels, sensitive or ionic $\mathrm{pH}$, and chemical reactions, as is the case of photocrosslinked hydrogels or enzymatically crosslinked. This paper aims to review the main strategies currently used for the formation of injectable hydrogels and, in addition, to show brief results on the formation of injectable hydrogels based on chitosan by physical and chemical crosslinking.
\end{abstract}

KEYWORDS: Polymer, hydrogel, injectable, crosslinking, biomaterial.

* Harremanetan jartzeko / Corresponding author: Sheila Maiz-Fernández, Kimika Makromolekular taldea (LABQUIMAC), Kimika Fisikoa Saila, Zientzia eta Teknologia Fakultatea, Euskal Herriko Unibertsitatea (UPV/EHU), Barrio Sarriena s/n 48940, Leioa, Euskal Herria. - sheila.maiz@bcmaterials.net - https://orcid.org/

Nola aipatu / How to cite: Maiz-Fernández, Sheila; Pérez-Álvarez, Leyre; Ruiz-Rubio, Leire; Vilas-Vilela, José Luis (2020). «Hidrogel injektagarriak eta haien aplikazioak ehun ingeniaritzan»; Ekaia, 37, 2020, 129-143. (https://doi.org/10.1387/ekaia.20837).

Jasoa: 10 maiatza, 2019; Onartua: 14 urria, 2019.

ISSN 0214-9001 - eISSN 2444-3255 / (c) 2020 UPV/EHU

cc)(-) Obra hau Creative Commons Atribución 4.0 Internacional-en

lizentziapean dago 
Sheila Maiz-Fernández, Leyre Pérez-Álvarez, Leire Ruiz-Rubio, José Luis Vilas-Vilela

\section{SARRERA}

Hidrogelak ahalmen hidrofiliko handia eta ura edo bestelako fluido biologikoak barnean mantentzeko gaitasuna duten hiru dimentsioko sare polimerikoak dira. [1] Sare polimeriko horiek deformatzeko ahalmena eskaintzen dute, berez daukaten malgutasuna dela eta. Horrela, disolbatzaile molekulak egituraren barnean mantetzeko gai dira disolbatu barik. XX. mendetik aurrera, hidrogelak ukipen lente modura erabiltzen hasi zirenetik, haien erabilera areagotuz joan da. Gaur egun hainbat aplikazio biomedikotan erabiltzen dira, hala nola farmakoen emate eta askatze kontrolatuan [2], kosmetika arloan betetze-material modura [3] edo hiru dimentsioko zelula-aldamio (scaffold) gisa ehun bizidunen birsorkuntzan [4].

Hiru dimentsioko eraikuntza hauek material biologikoz eratuta daude, hala nola zelulaz, proteinaz edo hazkuntza faktorez, eta egiturazko materialez, oro har material polimerikoz. Scaffoldek bete behar duten propietate nagusia giza zelulaz kanpoko matrizeen (ECM) antza izatea da. Horregatik, material polimerikoak oso aproposak dira matrize horiek antzeratzeko, haien hiru dimentsioko egituragatik, elastikotasunagatik, eta ur kantitate handiak eta eduki biokimikoak biltegiratzeko eta askatzeko gaitasuna dutelako. Ehun ingeniaritzak bereizte eta proliferazio zelularra sustatzen duten mikroingurune zelularrak imitatzeko gai diren materialen premia dauka, eta horrek material mota horien fabrikazioaren garrantzia sustatu du [5]. Hidrogel injektagarriok gorputzean injektatu baino lehen likido egoeran aurkitzen dira, eta, behin ingurune fisiologikopean, kanpo estimulu ( $\mathrm{pH}$, tenperatura...) baten bidez sol-gel trantsizioa jasaten dute. Ondorioz, gelifikazioa gertatzen da injektaturiko lekuan (1. irudia) [6]. Propietate horri esker, ohiko hidrogelak dituzten desabantailak gainditzen dira; izan ere, hidrogel injektagarriak ebakuntza kirurjikoak saihesten ditu, metodo ez-inbasiboak direlako eta akzioa injektaturiko lekuan gertatzen delako. Egitura injektagarri hauek oso interesgarriak dira ikuspuntu klinikotik ehunen edozein akats betetzeko gai direlako, nahiz eta halakoek forma eta tamaina irregularra izan.

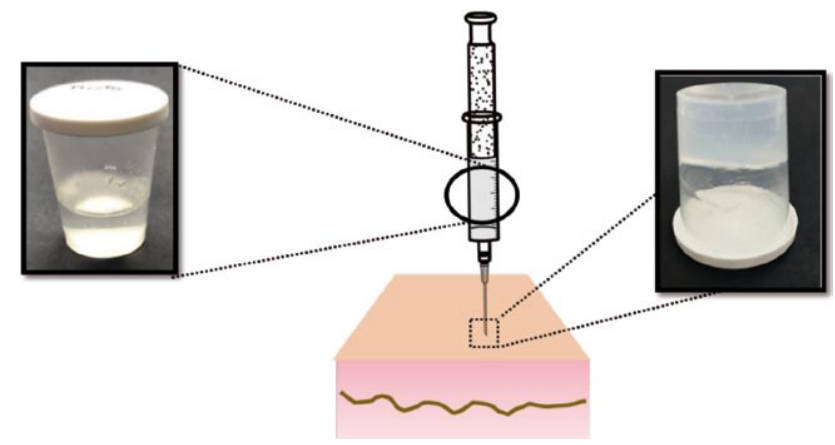

1.irudia. Sol-gel trantsizio zelulen presentzia hidrogel injektagarrietan. 
Hidrogel hauen ekoizpenerako jatorri natural zein sintetikoa duten polimeroak erabili ohi dira. Hidrogel injektagarrien garapenerako gehien erabili diren polimero naturalak honako hauek dira: agarosa [5], alginatoa [6] (itsas algen pareta zelularrean aurkitzen dena), azido hialuronikoa [7] (animalia helduen zenbait ehunetan aurkitzen dena) eta kitosanoa [8] (krustazeo oskoletatik lortzen ahal dena). Polisakarido horiek modu onuragarrian interakzionatzen dute in vivo, eta, gainera, giza zelulaz kanpoko matrizearen antza daukate. Bestalde, gelatina [9], kolagenoen hidrolisitik sintetizatua, oso erabilia izan ohi da. Ildo beretik, amilosa eta amilopektina [10], almidoiaren osagai nagusiak direnak, hidrogel injektagarrien formulazio berrien ikerkuntzan asko aztertu diren bestelako biopolimeroak dira. 2. irudian, aipatutako biopolimeroen egitura kimikoa adierazten da.

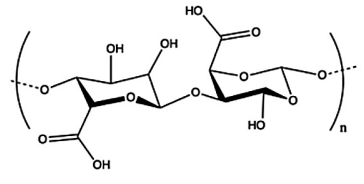

Alginato

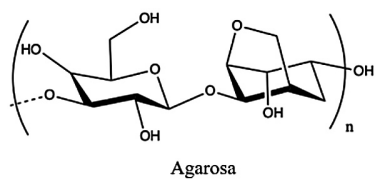

Agarosa

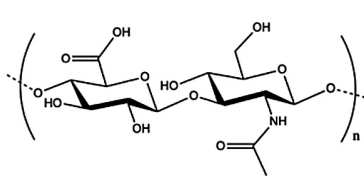

Azido hialuronikoa
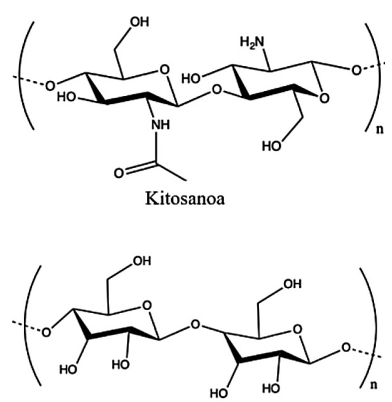

Amilosa

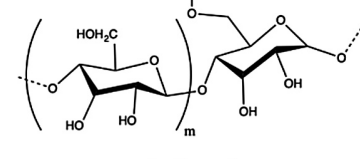

Amilopeptina

2. irudia. Hidrogel injektagarrien sintesirako gehien erabiltzen diren polimero naturalen egitura kimikoak.

Polimero naturalek daukaten abantaila garrantzitsuena biodegradagarritasuna da. Polimero sintetikoetan, ordea, propietate kimikoak, hala nola pisu molekularra, egitura, dentsitate eta abar, zehatzagoak dira, eta, horren ondorioz, polimero horietaz osaturiko egiturak kontrolatuagoak dira. Azken urteotan, askotariko polimero sintetiko biobateragarriak erabili dira biomedikuntzan. Hala ere, gehien ikertu direnak poli(etilenglikol)-a (PEG) [11], poli(binil alkohola) (PVA) [12], poli( $N$-isopropilakrilamida) (PNIPAAm) [13], poli(propilen fumaratoa) (PPF) [14], poli(etilen oxidoa) (PEO) [15] eta poli(propilen oxidoa) (PPO) dira [16]. (3. irudia) 
<smiles>C=C(C)COC(=O)/C=C/C(=O)OC(=C)CO</smiles>

PPF<smiles>CCC(C)C(=O)NC(C)C</smiles>

PNIPAAm<smiles>COCCC[Te]O</smiles>

PEG<smiles>CC(C)C(O)CC(C)(C)C</smiles>

PVA

3. irudia. In situ hidrogelen fabrikazioan gehien erabiltzen diren polimero sintetikoen egitura kimikoak.

In situ gelifikazioa hainbat mekanismoren bitartez gerta daiteke, eta, horien artean, lotura kobalente berrien bidez sortzen diren mekanismo kimikoak edo elkarrekintza fisiko itzulgarrietan oinarritzen diren mekanismo fisikoak bereiz daitezke. Alde batetik, hidrogel kimikoek egonkortasun mekaniko handia eskaintzen dute. Hala ere, gelifikazio denborak ere luzeagoak izaten dira [17]. Hidrogel hauen beste desabantaila bat gurutzaketa eragiteko erabiltzen diren kanpoko substantziak edo agenteak dira; izan ere, sarritan toxizitate indize altuak dituzte. Halaber, gurutzaketa fisikoa, gelifikazio denbora laburragoak izateaz gain, gurutzaketa agenterik gabe egin daiteke.

\section{IN SITU GELIFIKAZIO MEKANISMOAK}

Gelifikazio prozesua gertatzeko hainbat estimulu daude. Hori dela eta, hidrogel injektagarri mota anitz desberdintzen dira: termosentikorrak [10], pH-sentikorrak [18], fotosentikorrak [19], gurutzaketa entzimatikoz gurutzaturiko hidrogelak [20], edo erantzun bikoitza duten hidrogelak [7].

\subsection{Hidrogel termosentikorrak}

Polimero batzuek beren agregazio egoeran edo disolbagarritasunean aldaketak jasan ditzakete tenperaturaren eraginez. Arlo honetan, tenperatura horrek eragindako nahaskortasun-aldaketari goi edo behe nahaskortasun tenperatura kritiko deritzo (UCST, Upper Critical Solution Temperature eta LCST, Lower Critical Solution Temperature, hurrenez hurren). UCST bi osagaien banaketa gertatzeko tenperatura maximoa da, tenperatura ho- 
rretatik gora bi osagaiak guztiz nahaskorrak dira. Bestalde, LCST alderantzizko prozesuari dagokio; tenperatura hori duten materialek likidotik (giro tenperatura) gorputz tenperaturan gelifikazioa induzitzeko erabiltzen dira. Zehazki, polimeroetan fase trantsizio hori ezaguna da, eta osagai hidrofobikoen eta hidrofilikoen elkarrekintzen arteko oreka aldaketaren ondorioz gertatu ohi da [21]. Adibidez, LCST duten polimeroetan, LCST baino tenperatura baxuagotan polimeroaren eta uraren arteko hidrogeno loturak polimero-polimero elkarrekintza hidrofobikoak baino ugariagoak dira, eta, ondorioz, haien disolbagarritasuna faboratzen da. Bestalde, LCSTa gainditzen denean, hidrogeno loturak ahultzen dira, eta elkarrekintza hidrofobikoak nagusitzen dira, eta, ondorioz, polimeroa prezipitatzen da. PNIPAAm-ek LCSTa tenperatura fisiologikotik $\left(32{ }^{\circ} \mathrm{C}\right)$ hurbil erakusten du, eta giza gorputzaren tenperaturan fase trantsizio bat jasaten du. Horregatik, azken urteotan, gelifikazio termosentikorrerako gehien erabili den makromolekula da [15] (4. irudia). Sarritan, polimero sintetiko hau hidrogel injektagarrien sintesirako erabilia izan da beste biopolimero natural batzuekin kopolimerizatuz.

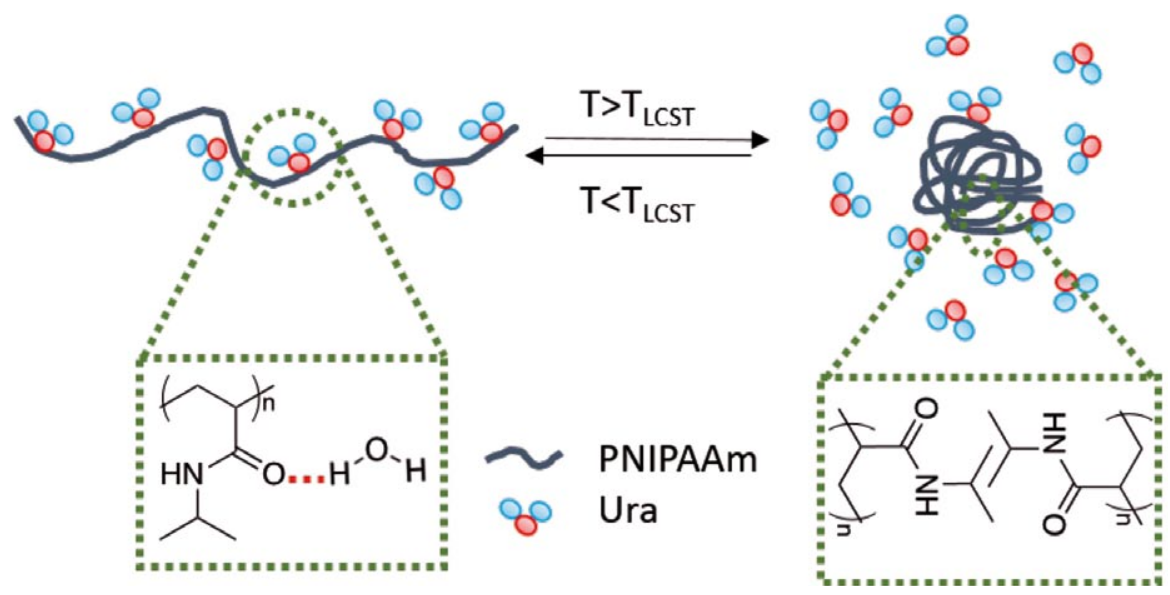

4. irudia. PNIPAAm-ren fase trantsizioa LCSTaren menpean.

Bestelako polimero sintetikoak ere erabili ohi dira hidrogel injektagarriak garatzeko, hala nola polimero sintetiko anfifilikoak (hau da, alde hidrofiliko eta alde hidrofobikoa dituztenak). Arlo honetan, sistema termosentikor ohikoena PEO-PPO-PEO (Pluronic (®) da. Sistema hauetan, PPO polimero katea PEO kateak baino hidrofilikoak dira, eta, beraz, PEO-PPOPEO kopolimeroa inguru urtsuan eta kontzentrazio egokian, alegia, mizelen kontzentrazio kritikoan (MKK), beren buruarekin agregatzen dira, eta mizela egiturak sorrarazten. Mizela horiek sol-gel trantsizioa jasaten dute tenperatura aldaketaren ondorioz, eta, gainera, tenperatura hori moldaga- 
Sheila Maiz-Fernández, Leyre Pérez-Álvarez, Leire Ruiz-Rubio, José Luis Vilas-Vilela

rria da polimeroaren pisu molekularraren edo konposizioaren arabera [13]. Tenperaturaren igoerak MKKaren jaitsiera dakar, eta, horregatik, tenperatura baxu samarretan $\left(\mathrm{T}<\mathrm{T}_{\text {sol-gel }}\right)$ mizelen eraketa bultzatzen da. Tenperatura altuetan, ordea, mizelen paketatzeak gel makroskopikoaren eraketa bultzatzen du (5. irudia). Hala ere, PNIPAAm polimeroarekin gertatzen den moduan, Pluronic $\AA$-ren aplikazioa biomedikuntza arloan oso mugatuta dago, biodegradagarria ez delako, eta horregatik, eskuarki, bestelako polimero biodegradagarriekin kopolimerizatzen da, adibidez, poli(azido laktikoa)-rekin, poli(kaprolaktona)-rekin edo poli(hidroxibutiratoa)-rekin [22].

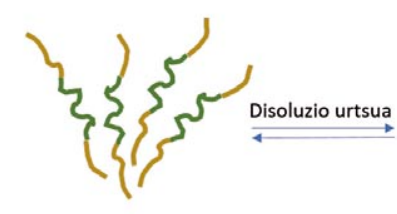

Bloke hidrofilikoa

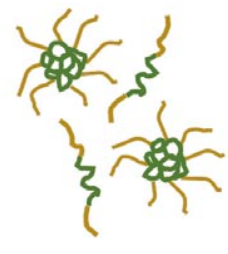

Mizelak T $<$ LCST

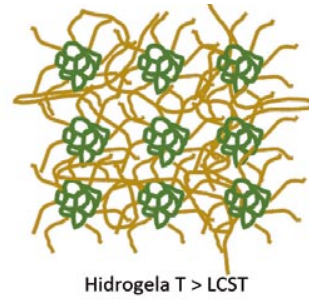

5. irudia. Pluronic $₫$ makromolekularen gelifikazio prozesuaren oinarriaren irudi eskematikoa.

Polimero naturalak erakargarriak bilakatu dira hidrogel termosentikorren garapenerako. Arlo honetan azpimarratu daitekeen ikerketa Chenite eta bestek $[23,24]$ argitaratutakoa da. Horretan, kitosanoan oinarritutako hidrogel injektagarri termosentikorra garatu zen. Kitosanoa polimero natural, lineal eta kationikoa da. Izaera kationiko horrek amino funtzio-taldeak ematen dio. Horregatik, $\mathrm{pK}_{\mathrm{a}}(\sim 6.5)$ baliotik beherako $\mathrm{pH}$ tartean positiboki kargatuta agertuko da $\left(-\mathrm{NH}_{3}{ }^{+}\right)$. Baina $\mathrm{pK}_{\mathrm{a}}$-ren baliotik gorako pH-balioetan, amino funtzio-taldea molekula arteko eta molekula barneko hidrogeno loturak eratzeko gai izango da. Horregatik, kitosanoa disolbaezina da disolbatzaile eta ingurune gehienetan, disoluzio azidoetan izan ezik. Baldintza azidoetan amino taldeak protonatuta agertzen dira, eta, ondorioz, aldarapen elektrostatikoak sortzen dira kate polimeriko guztian zehar. Aldarapen horiei esker, kate polimerikoen artean sortzen diren erakarpen indarrak (hidrogeno loturak) apurtzen dira, eta kitosanoa $\mathrm{pH}$ azidoetan disolbatzea posiblea da. Chenite eta laguntzaileek kitosanoaren disolbagarritasun arazoa konpondu zuten polisakaridoa $\beta$-glizerol fosfato disodiko ( $\beta$-GP) gatz basikoarekin nahastuz. Hidrogel horren berezitasuna da gatz basikoaren gehikuntzak interakzio hidrofobikoen eta hidrogeno lotura itzulgarrien kontrola ahalbidetzen duela. Horrela, kitosanoa disoluzioan manten daiteke $\mathrm{pH}$ neutroan eta tenperatura baxuetan. Hala ere, tenperaturaren igoerak kitosanokitosano interakzioa sustatzen du, eta horrek tenperatura fisiologikotik hurbil gertatzen den gelifikazio espontaneoa dakar (6. irudia). 
Kitosanoaz gainera, hidrogel termosentikorrak sortzeko gaitasuna daukaten bestelako polimero naturalak erabili izan dira. Adibidez, gelatina eta agarosa, amilosa eta amilopeptina edo zelulosaren eratorriak dira ohikoenak. Zelulosaren eratorrien kasuan, horiek hidrofobikoki eraldatzen dira, eta tenperatura igo ahala ura disolbatzaile gisa ahulduz doa, eta polimeropolimero elkarrekintzak nagusitzen dira eta polimeroen gelifikazioa eragiten. Gelifikazio-mekanismo hori metilzelulosa eta hidroxipropilzelulosa konposatuetan beha daiteke, adibidez.

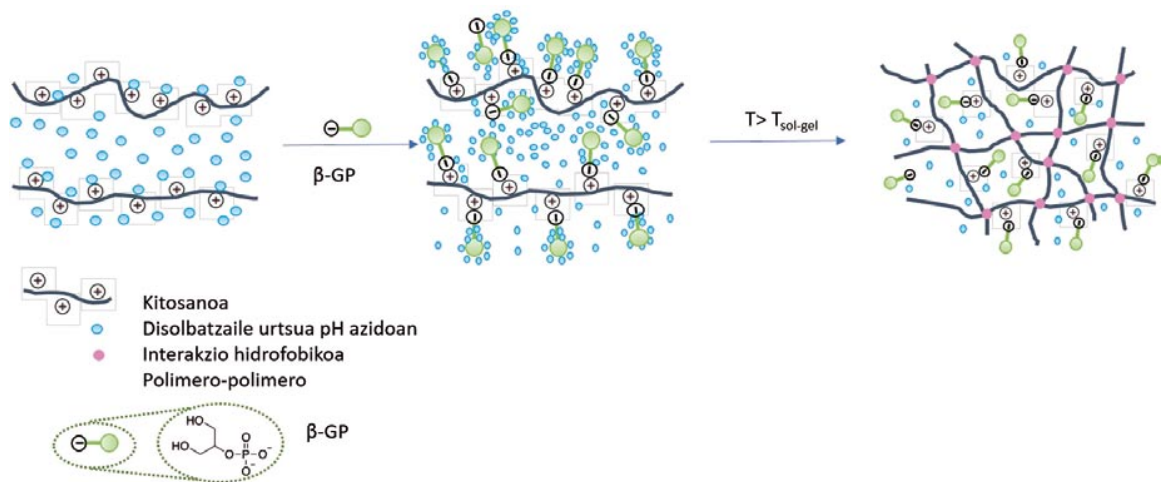

6. irudia. Kitosanoan eta $\beta$-GP-n oinarrituta dauden hidrogel termosentikorren gelifikazio mekanismoa inguru fisiologikoan.

\subsection{Ionikoki gurutzatutako hidrogelak}

Ionikoki gurutzatuta dauden hidrogelak anioi edo katioi di/tribalenteen eta kargatutako kate polimerikoen arteko elkarrekintza elektrostatikoetan oinarritzen dira. Hidrogel mota horietatik aipagarriena alginatoa da. Alginatoa algetatik datorren polisakarido natural anionikoa da. Gelak eratzeko gaitasun handia dauka disoluzioan katioiak gehituz, hala nola kaltzioa $\left(\mathrm{Ca}^{2+}\right)$, zinka $\left(\mathrm{Zn}^{2+}\right)$ edo magnesioa $\left(\mathrm{Mg}^{2+}\right)$. Katioi horiek $\mathrm{pH}$ egokian $\left(\mathrm{pK}_{\mathrm{a} \text {, alginato }} \approx 3,5\right)[25]$ alginatoaren osagaiak diren azido manuronikoaren eta azido guluronikoaren talde karboxilatoekin $\left(-\mathrm{COO}^{-}\right)$interakzionatzen dute, eta gelifikazioa eragiten dute zubi ionikoak eratzen dituztelako (7. irudia). Ikertzaileek alginato hidrogel ionikoak garatu dituzte $\mathrm{pH}$ egokian $(\approx 4,5)$ kaltzio kloruroa eta beste gatz batzuk gehituz. Hidrogel horien arazoetariko bat da baldintza fisiologikoetan egonkortasun mekaniko txikia dutela. Horregatik, hidrogel mota horiei gehienetan gurutzaketa kimikoa gehitzen zaie egonkortasun mekanikoa hobetu nahian. Kasu horietan, lotura bikoitzekin (talde akrilikoekin, binilikoekin...) eraldatutako alginato hidrogelak nabarmendu daitezke. Eraldatutako kate polimeriko horiek kaltzio katioi dibalenteekin interakzionatuz fisikoki gurutza daitezke, eta, lo- 
Sheila Maiz-Fernández, Leyre Pérez-Álvarez, Leire Ruiz-Rubio, José Luis Vilas-Vilela

tura bikoitzari esker, kimikoki ere baie. In situ gertatzen den gelifikazio kimikoa normalean argi ultramorearen (UM) esposizioaren ondoren gertatzen da fotohasarazle baten gehikuntzaren ondorioz, hala nola 2-metil-1-[4(hidroxietoxi)fenil]-2-metil-1-propanona edo 2-hidroxi-4'-(2-hidroxietoxi)2-metilpropiofenona gehitu ondoren [26].
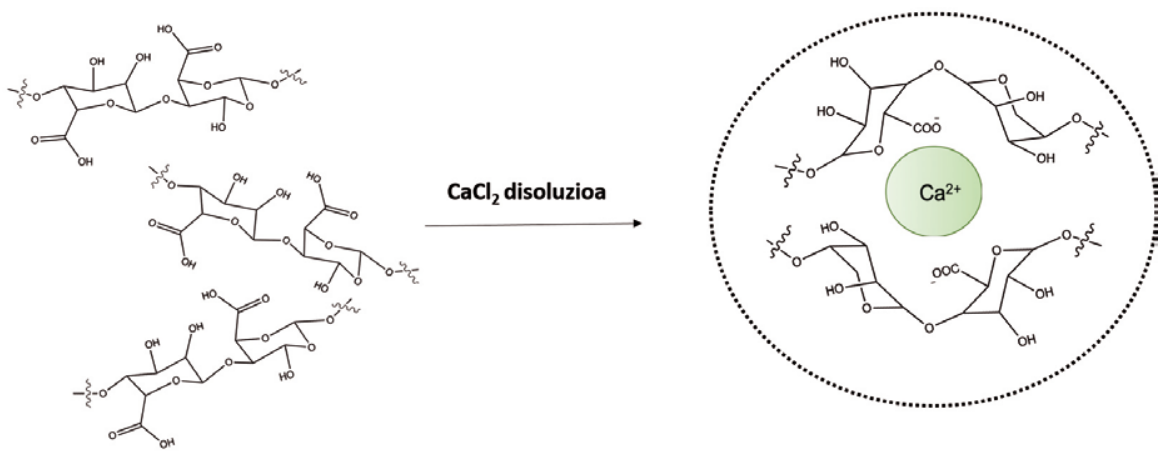

7. irudia. Alginato/ $\mathrm{Ca}^{2+}$ gelifikazioaren irudi eskematikoa.

\subsection{Fotogurutzatutako hidrogelak}

Argi UM edo ikusgaiaren bidezko monomeroen polimerizazioak sakonki ikertu dira azken urteotan in situ gelifikazioa bermatzeagatik. Lortutako emaitza gehienak biomedikuntza arlotik kanpo dauden bestelako aplikazioetan erabili dira, monomero gehienak zitotoxikoak baitira [27].

Polimerizatutako monomero horien gelifikazio mekanismoak eskuarki aurretik azaldutako bi mekanismo mota biltzen ditu. Alde batetik, hidrogel aurreosatua aurkitzen da polimero kateen arteko interakzio fisikoetan oinarrituz, eta, ondorioz, polimeroak dituen talde erreaktiboak gurutzatuko dira argi UM edo ikusgaiaren bitartez, eta lotura kobalente berriak eratuko dituzte. Horrela, lortutako hidrogelek egonkortasun mekaniko handiagoa izango dute inguru fisiologikoetan. Azken urteotan hidrogel fotogurutzatuen ekoizpenerako gehien erabili diren polimeroak hauek izan dira: PEG akrilatoa edo metakrilatoa, PVA deribatuak eta polisakarido eraldatuak, hala nola azido hialuroniko metakrilatoa eta dextrano metakrilatoa. Hidrogelen disoluzio aitzindaria gorputzean injektatzen da larruazalpetik, eta, ondorioz, argi UM edo ikusgaiaren azpian jartzen da, eta hala in situ gelifikazioa lortu (8. irudia). Adibidez, dextrano metakrilatoan oinarritutako hidrogel injektagarriei buruz sakonki ikertu da, eta gelifikazio denbora aldakorra lortu da, 90 segundotik 5 minutura bitartekoa, hasarazlearen kontzentrazioaren eta talde metakrilatoen ordezkapen mailaren arabera [28]. Oso ikertuak izan diren bestelako adibideak PEG diakrilatoan oinarritzen 
dira. Polimero hori eskuarki kopolimerizatzen da, adibidez poli( $\alpha$-hidroxiazido)-arekin edo poli(fumarato propilen-ko-etilenglikol)-arekin; izan ere, azken horrek asegabetasun puntu desberdinak aurkezten ditu polimero katean zehar, zeinek erreaktibotasun gehiago ematen dioten, eta, ondorioz, gelifikazio denbora murrizteko edo propietate mekanikoak hobetzeko aukera paregabea eskaintzen du.
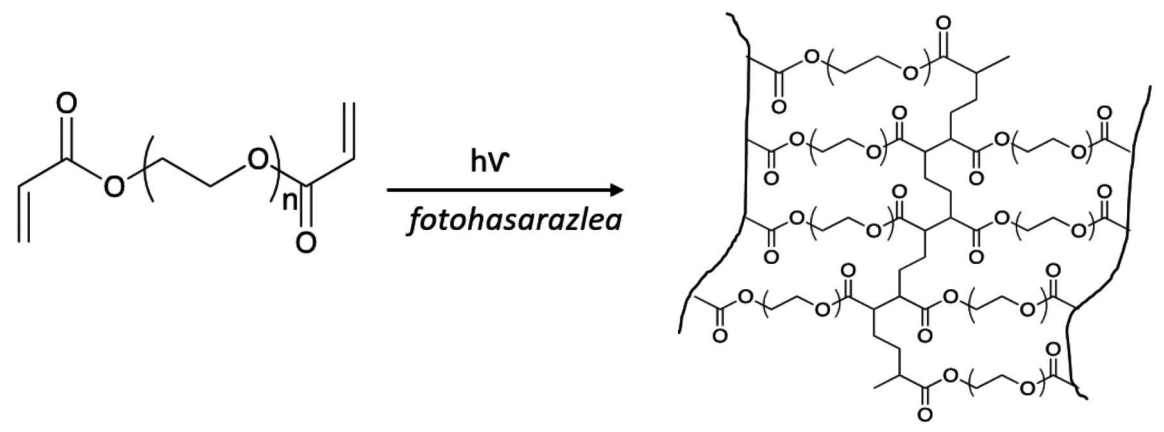

8. irudia. Polimetakrilatoan oinarritutako hidrogel injektagarriaren fotogurutzamendua adierazteko irudi eskematikoa.

\subsection{Erantzun bikoitzeko hidrogelak}

Fisikoki gurutzatutako hidrogel termosentikorren edo $\mathrm{pH}$-sentikorren desabantaila nagusiak egonkortasun eza eta gorputzpean aurkezten duten propietate mekaniko txarrak dira. Arazo horiek konpontzeko erantzun bikoitzeko hidrogelak garatu dira. Adibidez, Xiao et al. [30] pH-ari eta tenperaturari erantzuteko gai diren hidrogelak fabrikatu dituzte. Horretarako, PNIPAAm pH-ari erantzuteko gai diren segmentuekin, hala nola, poli(azido propilakriliko)-arekin (PPAA), poli(azido $N$-isopropilmalamiko)-arekin (PNIPMAA) eta poli(azido metakriliko)-arekin (PMAA) kopolimerizatu zuten. Emaitzetan oinarrituz hidrogeletan dauden talde karboxilikoei esker gelifikazioa $\mathrm{pH}$ basikoetan gertatzen zela $(\mathrm{pH} \approx 12-13)$ azaldu zuten. Beste aldetik, P(NIPAAm-ko-NIPMMA)-ren termosentikortasun ona PNIPAAm polimeroak duen LCST-ri esker ematen zela ondorioztatu zuten eta, horrela, erantzun bikoitza duen hidrogela ekoiztu zuten.

Aldi berean, fotosentikorrak eta termosentikorrak diren hidrogel sistemei ere erantzun bikoitzeko hidrogelak deritze. Adibidez, Tai et al. [31] uretan disolbagarria zen eta $32^{\circ} \mathrm{C}$-ko LCST-a duen kopolimero bat (PEGMEMA-PPGMA-EGDMA) ekoiztu zuten. Sistema horrek dituen talde metakrilikoak fotogurutzatzeko ahalmena aurkeztu dute eta gainera, LCST-ak ematen dion termosentikortasunarekin konbinatuz gero, propietate mekanikoen hobekuntza ekarri zuten. 
Sheila Maiz-Fernández, Leyre Pérez-Álvarez, Leire Ruiz-Rubio, José Luis Vilas-Vilela

\subsection{Entzimatikoki gurutzatutako hidrogelak}

Gurutzamendu kimikorako erabiltzen diren hasarazleen toxizitateak gurutzamendu entzimatikoaren garapena bultzatu du. Entzimek lotura kimikoak apurtzeko edota lotura berriak eratzeko aukera ematen dute beste metodo baino eraginkortasun handiagoarekin, izan ere, erreakzio denbora laburrak eta espezifikotasun handiak eragiteaz gain albo erreakzioak emateko aukera murrizten dute. Erreakzio entzimatikoak erreakzio baldintza leunetan ematen dira, hau da, ingurune urtsuetan, $\mathrm{pH}$ neutroetan eta tenperatura epeletan. Hidrogel kimikoen garapenerako gehien erabili diren entzima errefau peroxidasa, transglutaminasa, tirosinasa, fosfopanteteinil-transferasa eta lisil oxidasa dira. Errefau peroxidasa, HRP (Horseradish peroxidase) moduan ere ezaguna dena, hidrogelak entzimatikoki katalizatzeko entzima interesgarrienetariko bat da. Izan ere, denbora laburretan (4 minutu) erresistentzia mekaniko handia duten hidrogelak ekoizteko aukera ematen du. HRP-k fenolen akoplamendu oxidatzailea katalizatzen du hidrogeno peroxidoaren $\left(\mathrm{H}_{2} \mathrm{O}_{2}\right)$ presentzian (9. Irudia). HRP eta $\mathrm{H}_{2} \mathrm{O}_{2}$ sistema katalizatzaileak aldez aurretik talde fenolikoekin modifikatutako polimeroetan askotan erabili dira, hala nola, kitosanoarekin, azido hialuronikoarekin, dextranoarekin edota gelatinarekin, ondoren, ehun ingeniaritzan aplikatzeko. Adibidez, Feijen eta kolaboratzaileek [32] gurutzamendu entzimatikoa HRP entzima erabiliz aztertu zuten kitosanoan oinarritutako hidrogeletan. Lehendabizi, kitosanoak uretan aurkezten duen disolbaezintasuna konpontzeko, polisakaridoa azido glikolikoarekin modifikatu zuten eta, ondorioz, azido 3-(4-hidroxifenil) propionikoarekin modifikatu zuten HRP-ak polimeroaren talde fenolikoen akoplamendu oxidatzailea katalizatu ahal izateko. Gelifikazio denbora nahastearen (polimeroa $+\mathrm{HRP}+\mathrm{H}_{2} \mathrm{O}_{2}$ ) injekziotik eta baldintza fisiologikoetan 4 minututik 10 minutura gertatu zen talde fenolikoen ugaritasuna edo entzimaren kontzentrazioaren arabera.

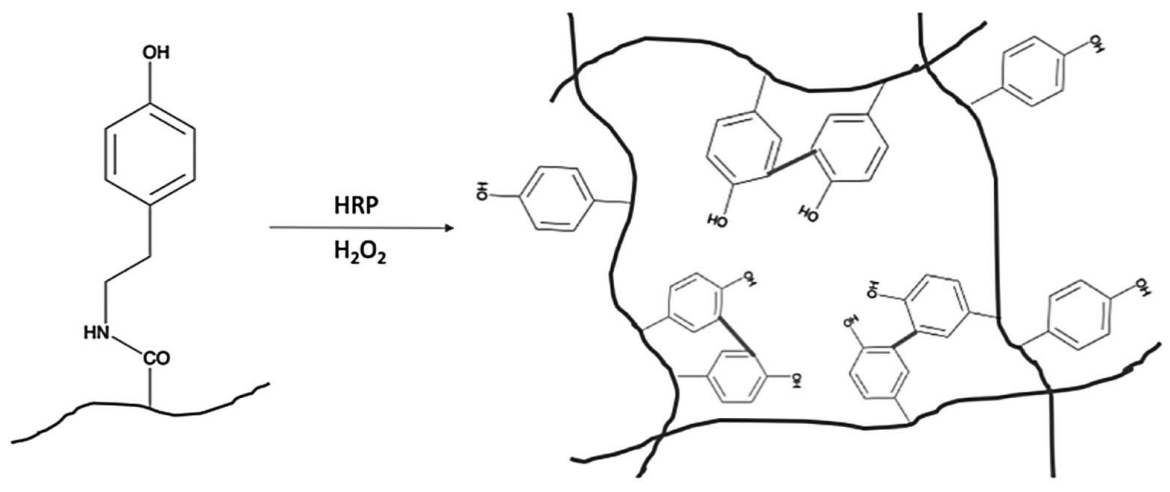

9. irudia. Aldez aurretik talde fenolikoekin modifikatutako polimero baten solgel trantsizioa gurutzamendu katalitikoaren bidez $\mathrm{HRP}$ eta $\mathrm{H}_{2} \mathrm{O}_{2}$ erabiliz. 


\section{APLIKAZIOAK EHUN INGENIARITZAN}

Ehun ingeniaritza jakintza-alor anitz bat-egiten duen esparrua da. Horrek materialen zientzia eta biozientzien oinarriak kontuan edukiz, ehun zelularrak berritu, konpondu, mantendu edo hobetzeko gai izango diren teknologia berrien garapenean oinarritzen da. Teknologia horiek funtzio biologikoak ordezkatu edo hobetzen dituzte eta horregatik, gaur egun, horren interes handia piztu dute. Ehun ingeniaritzaren estrategien helburu nagusia aldamio zelular edo scaffold ideal baten eraketa da [33]. Hazkuntza zelularra gorputz barneko inguru hiru dimentsiotako inguru aldakor batean gertatzen da, hainbat prozesu eta funtzio zelular sustatzen dituelarik, hala nola, migrazioa edota diferentziazioa. Aurretik ikusi den moduan, hidrogel polimeriko injektagarriak biomaterial oso egokiak dira in vivo-zko mikroinguru zelularrak imitatzeko eta, horregatik, gaur egun, mota askotariko ehunak birsortzeko ikerketetan asko erabiltzen dira, hala nola, gihar ehunak, kartilago ehunak, hezur ehunak, eta abar.

Pertsona helduen desgaitasunen kausa nagusienetarikoa hezur-akatsak dira. Nahiz eta autoinjertoa hezur-akatsak konpontzeko aukera erabiliena izan, era ditzaketen efektu kaltegarriak direla eta (albo erreakzioak, infekzioak...) nahiko mugatuta dago. Hori dela eta, hezur-ehunen ingeniaritzak arreta handia bereganatu du.

Ehun ingeniaritzan ikasketa askok kitosanoaren aplikazioa erakutsi dute hezur-ehunen konponketarako. Adibidez, Niranjan eta kolaboratzaileek [34] kitosanoan eta $\beta$-glizerol fosfato gatzan oinarritzen den hidrogel termosentikorra garatu zuten. Scaffold horren froga zelularrak osteblastoekin egin ziren eta matrize polimerikoa zelula horien diferentziazioa egiteko gaitasuna zuela frogatu zen. Bestaldetik, antibakterianoa, biobateragarria eta biodegradagarria zela behatu zuten eta horregatik, polisakarido eta gatz horietan oinarritutako hidrogelak hezur-ehunen birkonponketarako hautagai oso aproposak direla ondorioztatu zuten.

Polimero termosentikorrak, aurretik esan den moduan, hezur-ehunen akatsak konpontzeko oso aproposak diren materialak dira, izan ere, ehun gaixoak dituen akatsen formara eta tamainara moldatzeko gaitasuna daukatela frogatu dute. Adibidez, Bai eta lankideek [35] interakzio fisikoak eta gurutzaketa kimikoa konbinatzen dituen PNIPAAm-ean, ziklodextrinan eta adamantanoan oinarritutako hidrogel injektagarria garatu zuten. Ikertzaile horiek hezur konponketako probak egin zituzten, eta lortutako emaitzek frogatu zuten hazkuntza faktoreak eta zelulak hidrogel injektagarrietan hezur-ehuna 14 egunean erabat konpontzeko gai zirela.

Beste behar kliniko bat kartilago ehunen birsorkuntza da; izan ere, kartilagoaren lesio traumatikoek eta endekapenezko lesioek, oro har, pertsona helduen artean desgaitasunak sortu ohi dituzte. Horregatik, hidrogel injek- 
Sheila Maiz-Fernández, Leyre Pérez-Álvarez, Leire Ruiz-Rubio, José Luis Vilas-Vilela

tagarriek inpaktu kliniko handia daukate kartilagoaren hobekuntzan edo birsorkuntzan. Palumbo eta lankideek [5] kondrozitoak kapsulatzeko in situ hidrogel bat ekoitzi eta ezaugarritu zuten. Gelifikazioa 30 minutuan gertatu zen, eta lortutako hidrogelek hidrolisi entzimatikoarekiko erresistentzia paregabea eskaintzen zuten (28 egun). Gainera, inkubazio egun baten ostean behatu zen kondrozitoak hidrogelaren barnean modu eraginkorrean ugaltzen zirela. Beste kasu arrakastatsu bat arlo honetan, aurretik aipatutako Feijen eta lankideen [32] kartilago ehunen birsorkuntzarako hidrogela da. Aurretik esandakoa goraipatuz, kitosanoan oinarritutako hidrogel horren erakuntza HRPk katalizatutako gurutzaketa entzimatikoaren bitartez gertatzen da, kitosanoa talde fenolikoekin eraldatu ostean. Emaitzek adierazi zuten hidrogel hau hautagai aproposa dela kartilago ehunen birsorkuntzarako. Izan ere, propietate mekanikoak (1-5.5 kPa) eta gelifikazio denbora (10 stik 4 min-ra) egokiez batera, kondrozitoen hazkuntza esperimentuek gel horiek biobateragarritasun ona eta zelula ugalketako prozesua bultzatzen zituztela baieztatu zuten.

In situ hidrogelen beste aplikazio arlo bat gihar ehunen birsorkuntza da. Europako biztanleriari gehien erasaten dion gihar gaixotasuna gaixotasun arterial periferikoa da. Zoritxarrez, gaur egun, muskulu eskeletiko iskemikoa sendatzeko terapia gutxi izaten dira, eta gaurko biomaterialen erabilera ez da guztiz eraginkorra izan, ez baitituzte gihar-mikroinguruak ondo imitatzen. Ke et al. [36] bezalako ikertzaileek kitosano/ $\beta$-glizerolfosfatoan eta kolagenoan oinarritutako hidrogel termosentikor bat garatu zuten giharehunen birsorkuntzarako. Ikertzaile horiek frogatu zuten hidrogel barnean ko-kultibatutako zelula ama mesenkimalek desberdintzeko gaitasuna zutela eta, ondorioz, hidrogel injektagarri horrek etorkizun oparoa zuela gihar-zelula eskeletikoen kultiborako.

\section{ONDORIOAK}

Baldintza fisiologikotik hurbil sol-gel trantsizioa duten polimeroak etorkizun oparoa erakusten ari dira Ehun Ingeniaritzan, hidrogel injektagarriak sintetizatzeko aukera paregabea bilakatu direlako. Biomaterial horiek Ehun Ingeniaritzan asko erabili dira ehun ugari konpontzeko, gihar, kartilago edo hezur-ehunak esate baterako.

In situ gelifikazioa gertatzeko polimero sintetikoetan edo naturaletan oinarritzen diren hainbat mekanismo bereizten dira. Mekanismo horiek tenperatura, $\mathrm{pH}$ eta gatz kontzentrazio aldaketen ondorioz edo argi ultramorearen eta akzio entzimatikoaren ondorioz gerta daitezke. Estimuluekiko erantzuteko gaitasun desberdina eta erretikulazio mekanismo desberdina duten polimeroen konbinazioak hidrogel injektagarrien munduan aurrerapen handiak egiteko aukera eskaintzen du. Ondorioz, hazkuntza, ugaltze eta dife- 
rentziazio zelularra gertatzeko hiru dimentsioko mikroinguru biobateragarriak eratzeko aukera eskaintzen dute.

\section{ESKER ONAK}

Egileek dirulaguntza eskertzen dute ( $\mu 4 \mathrm{~F}$, ELKARTEK, Grupos de Investigación, IT718-13).

\section{BIBLIOGRAFIA}

[1] MAITRA, J., SHUKLA, V. K. 2014. «Cross-linking in Hydrogels - A Review». American Journal of Polymer Science, 4, 25-31.

[2] JEONG, B., BAE, Y. H., LEE, D. S., KIM, S. W. 1997. «Biodegradable block copolymers as injectable drug-delivery systems». Nature, $\mathbf{3 8 8}, 860-862$.

[3] VARMA, D. M., GOLD, G. T., TAUB, P. J., NICOLL, S. B. 2014. «Injectable carboxymethylcellulose hydrogels for soft tissue filler applications». Acta Biomaterialia, 10, 4996-5004.

[4] ZHU, J. 2010. «Bioactive Modification of Poly(ethylenglykol) Hydrogels for Tissue Engineering». Biomaterials, 31, 4639-4656.

[5] PALUMBO, F. S., FIORICA, C., DI STEFANO, M., PITARRESI, G., GULINO, A., AGNELLO, S., GIAMMONA, G. 2015. «In situ forming hydrogels of hyaluronic acid and inulin derivatives for cartilage regeneration». Carbohydrate Polymers, 122, 408-416.

[6] CHOU, A. I., AKINTOYE, S. O., NICOLL, S. B. 2009. «Photo-crosslinked alginate hydrogels support enhanced matrix accumulation by nucleus pulposus cells in vivo». Osteoarthritis and Cartilage, 17, 1377-1384.

[7] KONDIAH, P. J., CHOONARA, Y. E., KONDIAH, P. P. D., MARIMUTHU, T., KUMAR, P., DU TOIT, L. C., PILLAY, V. 2016. «A review of injectable polymeric hydrogel systems for application in bone tissue engineering». Molecules, 21, 1324-1335

[8] MA, G., YANG, D., LI, Q., WANG, K., CHEN, B., KENNEDY, J. F., NIE, J. 2010. «Injectable hydrogels based on chitosan derivative / polyethylene glycol dimethacrylate / N, N-dimethylacrylamide as bone tissue engineering matrix». Carbohydrate Polymers, 79, 620-627.

[9] WANG, W. B., HUANG, D. J., KANG, Y. R., WANG, A. Q. 2013. «Onestep in situ fabrication of a granular semi-IPN hydrogel based on chitosan and gelatin for fast and efficient adsorption of $\mathrm{Cu} 2+\mathrm{ion} »$. Colloids and Surfaces B: Biointerfaces, 106, 51-59.

[10] YANGLING, L., CHANG, L., YING, T., KUN, X., CUGE, L., PIXIN, W. 2014. «In situ hydrogel constructued by starch-based nanoparticles via a Schiff base reaction». Carbohydrate Polymers, 110, 87-94. 
Sheila Maiz-Fernández, Leyre Pérez-Álvarez, Leire Ruiz-Rubio, José Luis Vilas-Vilela

[11] WIELAND, J. A., HOUCHIN-RAY, T. L., SHEA, L. D. 2009. «Non-viral vector delivery from PEG-hyaluronic acid hydrogels Julie». Journal of Controlled Release, 120, 233-241.

[12] DRURY, J. L., MOONEY, D. J. 2003. «Hydrogels for tissue engineering: Scaffold design variables and applications». Biomaterials, 24, 4337-4351.

[13] KLOUDA, L., MIKOS, A. G. 2008. «Thermoresponsive hydrogels in biomedical applications -a review». Eurpoean Journal of Pharmaceutics and Biopharmaceutics, 68, 34-45.

[14] TAN, H., MARRA, K. G. 2010. «Injectable, biodegradable hydrogels for tissue engineering applications». Materials, 3, 1746-1767.

[15] RUEL-GARIÉPY, E., LEROUX, J. C. 2004. «In situ-forming hydrogels Review of temperature-sensitive systems». European Journal of Pharmaceutics and Biopharmaceutics, 58, 409-426.

[16] CHUNG, H. J., LEE, Y., PARK, T. G. 2008. «Thermo-sensitive and biodegradable hydrogels based on stereocomplexed Pluronic multi-block copolymers for controlled protein delivery». Journal of Controlled Release, 127, 22-30.

[17] ASSAAD, E., MAIRE, M., LEROUGE, S. 2015. «Injectable thermosensitive chitosan hydrogels with controlled gelation kinetics and enhanced mechanical resistance». Carbohydrate Polymers, 130, 87-96.

[18] RIZWAN, M., YAHYA, R., HASSAN, A., YAR, M., AZZAHARI, A. D., SELVANATHAN, V., SONSUDIN, F., ABOULOULA, C. N. 2017. «pH sensitive hydrogels in drug delivery: Brief history, properties, swelling, and release mechanism, material selection and applications». Polymers, 9, 4, 137.

[19] ELISSEEFF, J., ANSETH, K., SIMS, D., MCINTOSH, W., RANDOLPH, M., LANGER, R. 1999. «Transdermal photopolymerization for minimally invasive implantation». Proceedings of the National Academy of Sciences, 96, 3104-3107.

[20] YU, F., CAO, X., L, Y., ZENG, L., YUAN, B., CHEN, X. 2014. «An injectable hyaluronic acid/PEG hydrogel for cartilage tissue engineering formed by integrating enzymatic crosslinking and Diels-Alder "click chemistry"». Polymer Chemistry, 5, 1082-1090.

[21] ALLCOCK, H. R., DUDLEY, G. K. 1996. «Lower critical solubility temperature study of alkyl ether based polyphosphazenes». Macromolecules, 29, 1313-1319.

[22] Li, J., Stachowski, M., Zhang, Z.Switchable and Responsive Surfaces and Materials for Biomedical Applications. 2015, pp. 259-298.

[23] CHENITE, A., CHAPUT, C., WANG, D., COMBES, C., BUSCHMANN, M., HOEMANN, C., LEROUX, J., ATKINSON, B., BINETTE, F., SELMANI, A. 2000. «Novel injectable neutral solutions of chitosan form biodegradable gels in situ». Biomaterials, 21, 2155-2161.

[24] CHENITE, A., BUSCHMANN, M., WANG, D., CHAPUT, C., KANDANI, N. 2001. «Rheological characterisation of thermogelling chitosan/glycerolphosphate solutions». Carbohydrate Polymers, 46, 39-47. 
[25] DRAGET, K. I., SKJAK BRAEK, G., SMIDSOD, O. 1994. «Alginic acid gels: the effect of alginate chemical composition and molecular weight». Carbohydrate Polymers, 25, 31-38.

[26] JEON, O., POWELL, C., SOLORIO, L. D., KREBS, M. D., ALSBERG, E. 2011. «Affinity-based growth factor delivery using biodegradable photocrosslinked heparin-alginate hydrogels». Journal of Controlled Release, 154, 258-266.

[27] HENNINK, W. E., VAN NOSTRUM, C. F. 2012. «Novel crosslinking methods to design hydrogels». Advanced Drug Delivery Reviews, 64, 223-236.

[28] KIM, S. H., CHU, C. C. 2000. «Synthesis and characterization of dextranmethacrylate hydrogels and structural study by SEM». Journal of Biomedical Materials Research, 49, 517-527.

[29] BAHRAM, M., MOHSENI, N., MOGHTADER, M. Emerging Concepts in Analysis and Applications of Hydrogels. 2015.

[30] XIAO DING, X., XIAN ZHENG, Z., SI XUE, C., REN XI, Z., KENNEDY, J. F. 2007. «A strategy to introduce the pH sensitivity to temperature sensitive PNIPAAm hydrogels without weakening the thermosensitivity». Carbohydrate Polymers, 68, 416-423.

[31] TAI, H., HOWARD, D., TAKAE, S., WANG, W., VERMONDEN, T., HENNINK, W. E., STAYTON, P. S., HOFFMAN, A. S., ENDRUWEIT, A., ALEXANDER, C., HOWDLE, S. M., SHAKESHEFF, K. M. 2009. «Photo-cross-linked hydrogels from thermoresponsive PEGMEMA-PPGMAEGDMA copolymers containing multiple methacrylate groups: Mechanical property, swelling, protein release, and cytotoxicity». Biomacromolecules, 10, 2895-2903.

[32] FEIJEN, J., JIN, R., TEIXEIRA, L. S. M., DIJKSTRA, P. J., KARPERIEN, M., BLITTERSWIJK, C. A. VAN, ZHONG, Z. Y. 2009. «Injectable chitosan-based hydrogels for cartilage tissue engineering». Biomaterials, 30, 2544-2551.

[33] VAN VLIERBERGHE, S., DUBRUEL, P., SCHACHT, E. 2011. «Biopolymer-based hydrogels as scaffolds for tissue engineering applications: A review». Biomacromolecules, 12, 1387-1408.

[34] NIRANJAN, R., KOUSHIK, C., SARAVANAN, S., MOORTHI, A., VAIRAMANI, M., SELVAMURUGAN, N. 2013. «A novel injectable temperature-sensitive zinc doped chitosan/ $\beta$-glycerophosphate hydrogel for bone tissue engineering». International Journal of Biological Macromolecules, 54, 24-29.

[35] BAI, X., LÜ, S., CAO, Z., GAO, C., DUAN, H., XU, X., SUN, L., GAO, N., FENG, C., LIU, M. 2016. «Self-reinforcing injectable hydrogel with both high water content and mechanical strength for bone repair». Chemical Engineering Journal, 288, 546-556.

[36] KE, D., YANG, Z., YU-LONG, Z., JIAN-ZHONG, X. 2013. «Injectable thermosensitive chitosan/-glycerophosphate/collagen hydrogel maintains the plasticity of skeletal muscle satellite cells and supports their in vivo viability». Cell biology international, 37. 